\title{
EVIDENCE BASED PRACTICE IN USING ANTIBIOTICS FOR ACUTE TONSILLITIS IN PRIMARY CARE PRACTICE
}

\author{
Valentina Risteska Nejashmikj ${ }^{1}$, Snezana Stojkovska ${ }^{2}$, Irena Kondova Topuzovska ${ }^{2}$, Katarina Stavrikj ${ }^{1}$ \\ ${ }^{1}$ Center for Family Medicine, Medical Faculty Skopje \\ ${ }^{2}$ University Clinic for Infectious Diseases and Febrile Conditions, Medical Faculty Skopje, Republic of Macedonia
}

Corresponding author: Risteska Nejashmikj Valentina, Center for Family Medicine, Medical Faculty Skopje, st. 50 Divizija no.6, 1000 Skopje, R Macedonia, tel: 070-216970, e-mail: valentina.nejasmic@gmail.com

\section{ABSTRACT}

The increased use of antibiotics for acute tonsillitis is a public health problem. $80 \%$ of the antibiotic prescriptions for acute tonsillitis are done in the Primary Care practice (PCP). The inappropriate use of the antibiotic causes bacterial resistance and treatment failure. Only patients with acute tonsillitis caused by Group A beta-hemolytic streptococcus (GAS) have benefit of the antibiotic treatment, which is a predict cause in 5-20\%. In order to assess the antibiotic prescribing for acute tonsillitis by the doctors in the PCP in Macedonia we use the data from the national project about antibiotic prescribing for acute respiratory tract infections which was conducted in November 2014 during a period of 4 weeks as part of the E-quality program sponsored by the IPCRG. 86 general practitioners from Macedonia have participated. The group of 1768 patients, from 4 months to 88 years of age, with diagnosis of acute tonsillitis was analyzed. The antibiotic prescriptions according to the Centor score criteria were compared to the Cochran's guidelines which are translated and recommended as national guidelines. $88.8 \%$ of the patients with acute tonsillitis were treated with antibiotics, of which $52.9 \%$ with Centor score 0 to 2 were treated inappropriate. The diagnosis is mostly made based on the clinical picture and the symptoms. Only $(23.6 \%)$ of the patients were treated with antibiotics (Penicillin V and cephalexin) according to the guidelines.

We concluded that there is a low adherence to the national guidelines. The clinical assessment is not accurate in determining the etiology. Also, there is a high nonadherence in prescribing the first choice of antibiotics. We emphasize the need to change the general practitioners' prescription behavior according to the guidelines.

Key words: Centor score, acute tonsillitis, irrational antibiotic prescribing, antibiotic prescribing.

\section{INTRODUCTION}

The majority of the respiratory tract infections (RTIs) are treated in the general practice. Most infections are caused by a virus, and antibiotics are therefore unlikely to have any clinical benefit. Antibiotic resistance is a major concern globally. Antibiotic consumption increases the likelihood for an individual to develop bacterial resistance. [1] In Macedonia there have been increasing levels of antibiotic use and antimicrobial resistance. The national antimicrobial resistance surveillance data in 2015 showed high resistance, such as Staphylococcus aureus $43 \%$ resistant to meticillin, 20\% Streptococcus pneumoniae resistant to penicillin as well as high resistance of Gram-negative bacteria: Enterobacter spp (50\%) to vancomicin, Klebsiella pneumoniae (87\%) and Escherichia coli (66\%) to the third generation of cephalosporin. [2] Despite the widespread implementation and use of the guidelines, numerous studies showed inappropriately high level of use 
of antibiotics. $[3,4,5]$ The translated Cochrane guidelines have been provided by the Ministry of Health since 2007 in Macedonia, but the nonadherence to those guidelines continues. Concerning the antibiotic prescribing practices for tonsillitis in adults and children, the guidelines recommend antibiotic treatment only in patients who were likely to have Group A streptococcus infection based on the presence of at least 3 of 4 Centor criteria, or patients with two or more Centor criteria in the presence of a positive rapid antigen detection test (RADT). [6] More recently, the Centor score was modified by incorporating the patient's age, which allows the physician to place patients in low-, moderate-, or high-risk groups. The use of the McIsaac Modified Centor score has helped in decreasing the inappropriate antibiotic use by almost $88 \%$. [7] For cases meeting the clinical and/ or laboratory criteria of streptococcal tonsillitis the recommended agents include penicillin $\mathrm{V}$ or cephalexin, depending on the patient's antibiotic allergies. [8]

Factors influencing the antibiotic prescribing for respiratory tract infection are the doctors, the patients, and the pharmacy and health policies. [5] These factors may include the limited knowledge and experience of the medical practitioner, personal preference, and parental or patient pressure. $[9,10]$ Antibiotic prescribing for acute tonsillitis varies in different European countries. Increased antibiotic prescribing is noted in South European countries. [11] Doctors have a key role in prescribing the antibiotics for acute tonsillitis. Centor Score Criteria and RADT can increase the diagnostic safety and greatly help in reducing of antibiotic prescribing in PCP. $[12,13,14]$

\section{AIM}

The purpose of this study was to assess the use of the national guidelines among the general practitioners in the antibiotic prescribing for acute tonsillitis in Macedonia.

\section{MATERIAL AND METHODS}

The data are used from the national project about antibiotic prescribing for acute respiratory tract infections, which was conducted in November 2014 as a part of the E-quality program supported by the International Primary Care Respiratory Group (IPCRG). The study was carried by 86 general practitioners from different areas of Macedonia. A written informed consent was obtained from every doctor and a verbal informed consent from every patient and parent prior to fulfilling the questionnaires. The socio-demographic and medical data were obtained by means of personal or parental interviews. The survey was run from 3 November till 28 November 2014 (4 weeks). When the survey finished all the questioners were sent to the key researchers and the data base was established. The analyzed group contained 1768 patients, from 4 months to 88 years of age, with the diagnosis of acute tonsillitis J03 and J03.0 via the ICD-10CM diagnosis code. The antibiotic prescribing practice for acute tonsillitis has been compared with the Centor score criteria according to the actual national guidelines.

Statistical analysis. The data obtained were analyzing using STATISTICA for Windows version 7.

\section{RESULTS}

The total number of patients presented with acute tonsillitis was 1768 . Only 295 patients $(16.7 \%)$ had the diagnosis of streptococcal tonsillitis - J03.0, the rest of 1473 patients had the diagnosis of acute tonsillitis - J03. There is a difference in the distribution of the patients with acute tonsillitis by the age, with predomination of the group from 3-15 years old patients $(45.2 \%)$. (Table 1$)$

The majority of the antibiotic prescriptions were not strictly in accordance with the guidelines. The results obtained with this study show that 1571 patients $(88.8 \%)$ were treated with antibiotics. 832 patients $(52.9 \%)$ had Centor score 0,1 and 2 , and they received antibiotics although they didn't need it. $650(41.4 \%)$ patients had Centor score 3 and 4 , with very low risk for streptococcal infections, and probably most of them didn't need antibiotics, but they were still given them. Only 89 patients $(5.7 \%)$ with Centor score 5 received the appropriately antibiotics according to the guidelines. (Table 2)

The statistical analysis of the Chi $\left(\mathrm{X}^{2}\right)$ square test showed an increased antibiotic prescribing $\mathrm{p}=0.005$ in the group of patients with Centor score $0,1,2$ who are not for antibiotic treatment according to the guidelines. In the group of patients with Centor score $3,4+5$ it also showed an increased antibiotic prescribing, which is appropriate according the guidelines $\mathrm{p}<0.005$.

1255 patients $(71 \%)$ of the total of patients (1768) didn't have any investigations. In 2.4\% of the patients a microbiological smear was performed, in $3.6 \%$ a CRP test, and a peripheral blood sample in $373(21.1 \%)$. In 33 patients $(1.9 \%)$ 
Table 1. Distribution of patients by age

\begin{tabular}{|l|c|}
\hline Age groups & $\mathbf{N}(\mathbf{\%})$ \\
\hline$<\mathbf{3 y}$ & $212(12.0 \%)$ \\
\hline $\mathbf{3 - 1 5 y}$ & $799(45.2 \%)$ \\
\hline $\mathbf{1 5 - 4 4 y}$ & $515(29.1 \%)$ \\
\hline$>\mathbf{4 5 y}$ & $242(13.7 \%)$ \\
\hline
\end{tabular}

GAS tonsillitis should be treated with antibiotics, but in our survey $88.8 \%$ of the patients presented with acute tonsillitis were treated with antibiotics. In comparison to other countries, our level of harmonization with the guidelines is low similar to Pakistan were $98.5 \%$ of the patients were treated

Table 2. Distribution of patients according to the Centor sores and antibiotic treatment

\begin{tabular}{|c|c|c|c|}
\hline Centor score & Number of patients & Treated with antibiotics & Without antibiotics \\
\hline $\mathbf{- 1 / 0}$ & 192 & $165(86 \%)$ & $27(14 \%)$ \\
\hline $\mathbf{1}$ & 303 & $265(87 \%)$ & $38(13 \%)$ \\
\hline $\mathbf{2}$ & 462 & $402(87 \%)$ & $60(13 \%)$ \\
\hline $\mathbf{3}$ & 437 & $394(90 \%)$ & $43(10 \%)$ \\
\hline $\mathbf{4}$ & 276 & $256(93 \%)$ & $20(7 \%)$ \\
\hline $\mathbf{5}$ & 98 & $89(91 \%)$ & $9(9 \%)$ \\
\hline & 1768 & $1571(88.8 \%)$ & $197(11.2 \%)$ \\
\hline
\end{tabular}

Table 3. Used antibiotics in patients with tonsillitis

\begin{tabular}{|l|c|}
\hline Antibiotics & N (\%) \\
\hline Penicillin V & $247(15.7 \%)$ \\
\hline Cephalosporin & $272(17.3 \%)$ \\
\hline Amoxicillin & $291(18.5 \%)$ \\
\hline Amoxicillin/clavulanic acid & $622(39.6 \%)$ \\
\hline Macrolides & $66(4.2)$ \\
\hline Intramuscular therapy & $40(2.5 \%)$ \\
\hline Other antibiotics & $33(2.1 \%)$ \\
\hline
\end{tabular}

RADT was performed, of which 11 were negative. All 22 patients with positive RADT were treated with antibiotics.

The most prescribed antibiotics were amoxicillin/clavulonic acid in 622 patients $(39.6 \%)$, amoxicillin (18.5\%), and cephalosporin in 272 patients $(17.3 \%)$. In $7.9 \%$ of the patients cephalexin was prescribed as the first line recommended antibiotic, while in $9.4 \%$ the second and third generation of cephalosporin. Penicillin V, the national guideline-recommended antibiotic, was prescribed in only $15.7 \%$ of cases. Although there is high resistance of Group A streptococcus to macrolides, only $40(2.5 \%)$ of the patients were treated with it. Intramuscular therapy was administered in 33 patients $(2.1 \%)$. (Table 3 )

\section{DISCUSSION}

There is irrational and inappropriate prescribing of antibiotics and a broad spectrum of antimicrobial drugs in patients with acute tonsillitis in Macedonia. According to our guidelines around $20 \%$ of the patients who are highly suspected for with antibiotics. [12] Antibiotic treatment of tonsillitis was performed in $24 \%$ of the patients in London, UK. [15] The Dutch study showed that $71 \%$ of the patients were treated according to the guidelines. [16]

Unnecessary antibiotic treatment received 832 patients $(52.9 \%)$ of the patients with acute tonsillitis taking into account the Centor score and the national guidelines, but still there are doubts in the diagnostic safety. Using the Centor score has still not been included in the regular practice in Macedonia, but Macedonian doctors have the ability to recognize the patients for the antibiotic treatment $(p<0.005)$, but they don't have the ability to reduce the antibiotic prescribing in patients who don't need it $(\mathrm{p}=0.005)$. Using Centor score can greatly help in reducing the antibiotic prescribing. [ 12,17$]$ Our study showed that it would be useful for general practitioners to use national guidelines and the McIsaac Modified Centor score as it is not costly, and is sensitive and specific enough to reduce the unnecessary antibiotic prescriptions. Based on our study, we recommend that the score-only approach would save antibiotics prescriptions for $52.9 \%$ of our patients with scores of 0,1 or 2 . Although without a RAST test option, more antibiotics would be prescribed to patients with a score of 3 or 4 , and this percentage is better than the percentage of the patients that receive inappropriate antibiotics without a clinical score-based screening.

Centor score criteria include: 1 . Body temperature $>38^{\circ} \mathrm{C} 2$. Hyperemic, swollen tonsils with exudates 3 . Increased and painful lymph node on the neck 4. Absence of cough 5. Age: 3-15 
years score 1 point, $15-44$ years 0 point, $>45$ years -1 point. If each of these criteria is positive it is scored by 1 point. Patients with Centor score $4+5$ points should receive empirical antibiotic treatment with benzathine phenoxymethyl penicillin for 10 days, and in patients with Centor score 2 or 3 points RADT needs to be performed, and antibiotic prescribing is necessary only in the positive test $[9,10]$. In our country RADT is expensive for the patients, and due to that we included the patients with Centor score 3 for empirical treatment.

Following the score approach would significantly reduce the unnecessary antibiotics prescriptions, but the clinical assessment is not accurate in determining the microbial etiology. The guideline recommends performing a throat swab in patients who are suspected for group A streptococci on the basis of the symptom score. Only $29 \%$ of the patients performed some laboratory tests, most of them blood count, which is not according to the guidelines. RADT is performed only in $1.9 \%$ and throat swab is taken only in $2.4 \%$. Using RADT is limited for the primary care settings in Macedonia because it is not paid by the Insurance Fund.

RADT can further increase the diagnostics safety. [ 17, 18] Using the guidelines and the Centor score criteria can have an important impact on the treatment decisions by the doctors in the PHC, on the emergence of the antibiotic resistance; it can prevent the adverse effects of the antibiotics and reduce the unnecessary antibiotic prescriptions and antibiotic costs. $[13,19,20]$

Antibiotic prescriptions for acute tonsillitis corresponded poor with the recommended firstline choice in $23.6 \%$ of all prescriptions. The use of broad-spectrum antibiotics such as amoxicillin/clavulanic acid and cephalosporin second and third generation accounted for $39.6 \%$ and $9.4 \%$ of the GPs' prescriptions. This corresponds well with the national figures for the same time period from the Health Insurance Found where one third of all prescribed antibiotics are amoxicillin clavulanic acid. [21] The study in Ireland showed high prescription rate of antibiotics for acute tonsillitis in $78.05 \%$ of patients, of which $25.09 \%$ account for Co-amoxicillin while phenoxypenicillin in 42.7\%. [5] In Pakistan penicillin was mostly prescribed (34.1\%), especially amoxicillin/clavulanate; followed by macrolides (31.1\%), especially the second-generation agents, and fluoroquinolones (14.8\%). [12] In the Netherlands, about three-quarters of the prescribed antibiotics are the first-line choice. [16]
This is of importance taking into account the increased bacterial resistance in Macedonia. In Escherichia coli, resistance rates for cephalosporin are $73 \%$ and the resistance to penicillin among clinical isolates of Streptococcus pneumoniae is $18.75 \%$ in 2015 . [2] To date, $S$ pyogenes has remained universally susceptible to penicillin. Therefore, penicillin remains the firstline drug of choice for pharyngeal infections, as well as for complicated or invasive infections. [22]

This study clearly indicates that the guidelines need to be disseminated at a local level with a focus on reducing the antibiotics prescribing for minor respiratory conditions and on reducing the broad-spectrum antibiotics prescribing whenever necessary. Although the guidelines have been established since 2007 the nonadherence to these guidelines continues. The Ministry of Health started an intensive education of GP in Macedonia in the period of 2015-2017. Also, it is particularly important to increase the public awareness regarding the appropriate antibiotics use to decrease the patient pressure on GPs for the prescription.

\section{CONCLUSION}

We concluded that there is an increased and inappropriate prescribing of antibiotics and a broad spectrum of antimicrobial drugs in patients with acute tonsillitis in Macedonia. $88.8 \%$ of the patients presented with acute tonsillitis were treated with antibiotics. The most prescribed drug was amoxicillin-clavulanate. There is a low adherence to the national guidelines and the clinical assessment is not accurate in determining the etiology. Also, there is highly prevalent nonadherence in prescribing the first choice of antibiotics. The use of the guidelines and the Centor score criteria can help in rational prescribing, but it should be supported with laboratory tests (RADT or Microbiological smear) to verify the streptococcal infection especially with Centor score 3 . We emphasize the need to change the general practitioners' prescription behavior according to the guidelines. Education of the doctors by improving the communication skills, using the Centor score, RADT or microbiological smear, assisted by changes in the Insurance Fond, the Ministry of Health, patients education and broad education of the population with increasing the awareness of the inappropriate use of antibiotics for acute tonsillitis are needed.

Conflict of interest. We do not have a conflict of interest to declare. 


\section{REFERENCES}

1. Costelloe C, Metcalfe C, Lovering A, Mant $\mathrm{D}$, Hay AD: Effect of antibiotic prescribing in primary care on antimicrobial resistance in individual patients: systematic review and meta-analysis. BMJ 2010, 340:c2096.

2. Central Asian and Eastern European Surveillance of Antimicrobial Resistance Annual report 2016. http://www.euro.who.int/en/ publications/abstracts/central-asian-and-eastern-european-surveillance-of-antimicrobial-resistance.-annual-report-2016

3. Petersen I, Hayward AC; SACAR Surveillance Subgroup. Antibacterial prescribing in primary care. J Antimicrob Chemother 2007; 60 (suppl 1): i43-7.

4. Shapiro DJ, Hicks LA, Pavia AT, HershAL. Antibiotic prescribing for adults in ambulatory care in the USA, 2007-09. J Antimicrob Chemother 2013; 69:234-40.

5. Murphy M, Bradley CP, Byrne S. Antibiotic prescribing in primary care, adherence to guidelines and unnecessary prescribing-an Irish perspective. BMC Fam Pract. 2012;13: 43.

6. Centor RM, Witherspoon JM, Dalton HP, et al: The diagnosis of strep throat in adults in the emergency room. Med Decis Making. 1981;1(3):239-246.

7. McIsaac WJ, Goel V, To T. Low DE. The validity of a sore throat score in family practice. CMAJ 2000;163:811-815.

8. Marjukka Makela Article ID: ebm00007 (038.020) EBM Guidelines, 27.04.2011, www.ebm-guidelines.com available at http://zdravstvo.gov.mk/wp-content/uploads/2015/08/Gusobolka-i-tonzilit.pdf

9. Teng CL, Tong SF, Khoo EM, Lee V, Zailinawati $\mathrm{AH}$, Mimi $\mathrm{O}$, et al. Antibiotics for URTI and UTI-prescribing in Malaysian primary care settings. Aust Fam Physician 2011;40:325-9.

10. Teixeira Rodrigues A, Roque F, Falcão A, Figueiras A, Herdeiro MT. Understanding physician antibiotic prescribing behaviour: a systematic review of qualitative studies. Int $\mathrm{J}$ Antimicrob Agents 2013;41:203-12.

11. Plachouras D, Antoniadou A, Giannitsioti E, Galani L, Katsarolis I at all. Promoting prudent use of antibiotics: the experience from a multifaceted regional campaign in Greece. BMC Public Health 2014;14, 866.
12. Palla AH, KhanRA, Gilani AH, Marra F. Over prescription of antibiotics for adult pharyngitis is prevalent in developing countries but can be reduced using McIsaac modification of Centor scores: a cross-sectional study. BMC Pulm. Med. 2012;12:70.

13. Orda U, Mitra B, Orda S, Fitzgerald M, Gunnarsson R, Rofe G, Dargan A. Point of care testing for group A streptococci in patients presenting with pharyngitis will improve appropriate antibiotic prescription. EMA Emergency Medicine Australasia 2016; 28: 199-204.

14. Haldrup S, Thomsen RW, Bro F, Skov R, Bjerrum L, Søgaard M. Microbiological point of care testing before antibiotic prescribing in primary care: considerable variations between practices. BMC Fam. Pract 2017;18:1:9.

15. Crocker A. Factors affecting adherence to evidence-based guidelines in the treatment of URI, sinusitis, and pharyngitis Journal of Community Hospital Internal Medicine Perspectives 2013; 3: 20744 - http://dx.doi. org/10.3402/jchimp.v3i2.20744

16. Ong DSY, Kuyvenhoven MM, van Dijk L, Verheij TJM: Antibiotics for respiratory, ear and urinary tract disorders and consistency among GPs. J Antimicrob Chemother 2008, 62:587-592.

17. Gröndal H, Hedin K, Strandberg EL, André M, Brorsson A. Near-patient tests and the clinical gaze in decision-making of Swedish GPs not following current guidelines for sore throat - a qualitative interview study. BMC family practice 2015;16: 81 .

18. Atlas SJ, McDermott SM, Mannone C, Barry $\mathrm{M} \mathrm{J}$. The role of point of care testing for patients with acute pharyngitis. J Gen Intern Med 2005;20(8):759-76.

19. Fine AM, Nizet V, Mandl KD. Large-Scale Validation of the Centor and McIsaac Scores to Predict Group A Streptococcal Pharyngitis. Arch Intern Med 2012;172(11): 847-852.

20. Kose E, Kose SS, Akca D, Yildiz K, Elmas C, Baris M, Anil M. The effect of rapid antigen detection test on antibiotic prescription decision of clinicians and reducing antibiotic costs in children with acute pharyngitis. Journal of Tropical Pediatrics 2016;62: 308-315.

21. Health insurance found; Annual report for Consumption of prescriped drugs in Macedonia from the list of drugs covered by the Fund in 
primary care. http://www.fzo.org.mk/WBStorage/Files/Izvestaj\%20za\%20potrosuvacka \%20 na\%20lekovi \%20PPLL\%20-\%202015.pdf

22. Ferretti JJ, Stevens DL, Fischetti VA, editors. Streptococcus pyogenes : Basic Biology to Clinical Manifestations [Internet]. Oklahoma
City (OK): University of Oklahoma Health Sciences Center; 2016-. Chapter: Mechanisms of Antibiotic Resistance. Page 947. Available from: https://www.ncbi.nlm.nih. gov/books/NBK333424/

\title{
МЕДИЦИНА БАЗИРАНА НА ДОКАЗИ ВО КОРИСТЕЊЕ НА АНТИБИОТИЦИ ЗА АКУТЕН ТОНЗИЛИТИС ВО ПРИМАРНА ЗДРАВСТВЕНА ПРАКСА
}

\author{
Валентина Ристеска Нејашмиќ ${ }^{1}$ Снежана Стојковска² ${ }^{2}$ Ирена Кондова Топузовска², Катарина Ставриќ ${ }^{1}$
}

${ }^{1}$ Центар за семејна медицина, Медицински факултет Скопје,

2 Универзитетска клиника за инфективни болести и фебрилни состојби, Медицински факултет Скопје, Република Македонија

\section{Резиме}

Зголемената употреба на антибиотици за акутен тонзилитис претставува јавно здравствен проблем. 80\% од сите пропишани антибиотици за акутен тонзилитис се пропишани во Примарна здравствена заштита (ПЗ3). Несоодветното пропишување на антибиотици предизвикува бактериска резистенција и неуспех во третманот. Само пациентите со акутен тонзилитис предизвикан од бета хемолитичен стрептококус од Гр А (ГАС) имаат корист од антибиотски третман, за кој се предвидува дека е застапен во 5-20\% од случаите со акутен тонзилитис. Со цел да се процени пропишувањето на антибиотици на докторите од ПЗЗ во Македонија, за акутен тонзилитис, ние ги искористивме податоците добиени од Националниот проект за употреба на антибиотици за акутни респираторни инфекции кој беше спроведен во Ноември 2014 година како дел од Е-Програмата за квалитет. 86 матични доктори од Македонија зедоа учество. Беше анализирана група од 1768 пациенти на возраст од 4 месеци до 88 години со дијагноза на акутен тонзилитис. Пропишувањето на антибиотици беше споредувано според Центор скор критериумите од Кохрановите упатства кои се користат како национални упатства. $88.85 \%$ од пациентите со акутен тонзилитис добиле антибиотски третман од кои $52.9 \%$ со Центор скор 0 до 2 кои се лекувани непотребно со антибиотик. Дијагнозата во најголем број на случаи е базирана на клиничката слика и симптоми. Само $19.9 \%$ од пациентите биле третирани со антибиотици (Пеницилин В и цефалоспорини) согласно националните упатства.

Нашиот заклучок е дека постои слабо придржување до националните упатства. Клиничката проценка не е соодветна во потврдување на етиологијата. Исто така постои зголемено непридржување кон препишување на антибиотици од прва линија на избор. Се наметнува потреба од промена на однесувањето на општите лекари во поглед на препишување согласно упатствата.

Клучни зборови: Центор скор, акутен тонзилитис, ирационално препишување на антибиотици, пропишување на антибиотици. 